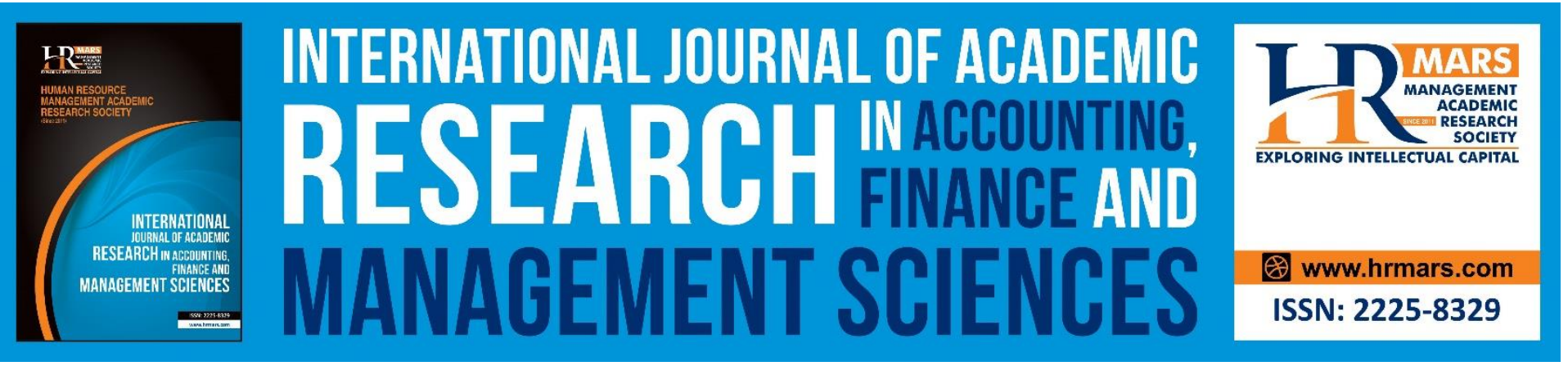

\title{
A Systematic Review of Literature on Reverse-Causality Relationship between Intellectual Capital and Firm's Financial Performance: Dynamic Panel Approach.
}

Siti Zaitun Saddam, Mohamad Nizam Jaafar

To Link this Article: http://dx.doi.org/10.6007/IJARAFMS/v11-i1/9334

DOI:10.6007/IJARAFMS /v11-i1/9334

Received: 11 January 2021, Revised: 12 February 2021, Accepted: 28 February 2021

Published Online: 19 March 2021

In-Text Citation: (Saddam \& Jaafar, 2021)

To Cite this Article: Saddam, S. Z., \& Jaafar, M. N. (2021). A Systematic Review of Literature on Reverse-Causality Relationship between Intellectual Capital and Firm's Financial Performance : Dynamic Panel Approach. International Journal of Academic Research in Business and Social Sciences, 11(1), 338-349.

Copyright: (c) 2021 The Author(s)

Published by Human Resource Management Academic Research Society (www.hrmars.com)

This article is published under the Creative Commons Attribution (CC BY 4.0) license. Anyone may reproduce, distribute, translate and create derivative works of this article (for both commercial and non-commercial purposes), subject to full attribution to the original publication and authors. The full terms of this license may be seen at: http://creativecommons.org/licences/by/4.0/legalcode

Vol. 11, No. 1, 2021, Pg. 338 - 349

http://hrmars.com/index.php/pages/detail/IJARAFMS

JOURNAL HOMEPAGE

Full Terms \& Conditions of access and use can be found at http://hrmars.com/index.php/pages/detail/publication-ethics 


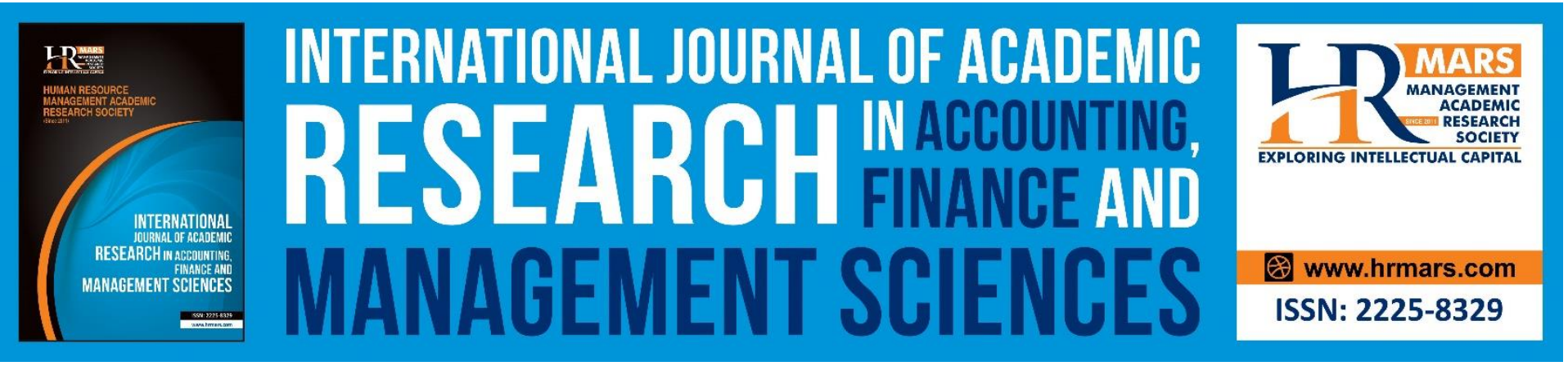

\title{
A Systematic Review of Literature on Reverse- Causality Relationship between Intellectual Capital and Firm's Financial Performance: Dynamic Panel Approach.
}

\author{
Siti Zaitun Saddam, Mohamad Nizam Jaafar \\ Faculty of Business and Management, Puncak Alam Campus, UiTM Selangor, 42300 Bandar Puncak \\ Alam, Selangor, Malaysia, AAGBS, Universiti Teknologi MARA. \\ Email: sitizaitun@uitm.edu.my.
}

\begin{abstract}
Intellectual capital (IC) is considered a valuable asset for the company's wealth creation and sustainable development; however, the findings regarding its impact on the company's financial performance and intellectual capital are limited and mixed. This paper aims to investigate the endogeneity problem on intellectual capital and firm's performance. In addition, past studies on this particular matter has been using static panel model. Though, the static model may not be able to resolve the reverse causality and endogeneity related to the relationship. Dynamic panel data approach is the best in estimating endogeneity and reverse-causality problems. Therefore, this study suggesting that in the future, researchers should use dynamic models to study these relationships. In order to control the endogenous effect, GMM model is used as it is appropriate for panel data, and it provides consistent results in the presence of endogeneity. This is due to the fact that, GMM estimator can produce consistent results in the presence of heteroscedasticity and resolve autocorrelation by differencing. Dynamic model is recommended as intellectual capital and firm performance is endogenous so the relationship between both of this variable and the regressor may also be correlated with error term.
\end{abstract}

Keywords: Endogeneity, Intellectual Capital, Firm's performance, Dynamic Panel Data, System GMM, Modified Value-Added Intellectual Capital (MVAIC).

\section{Introduction}

Company's financial performance mainly reflects the overall growth and financial status of the business sector in a specific period. A well-performing company will be able to maximize shareholder wealth and profitability, and then ultimately maintain its business (Naz \& ljaz, 2016). Successful companies represent an important part of developing countries. Many economists consider them in parallel with the engine when deciding their economic, social and political 
INTERNATIONAL JOURNAL OF ACADEMIC RESEARCH IN ACCOUNTING, FINANCE AND MANAGEMENT SCIENCES

Vol. 11, No. 1, 2021, E-ISSN: 2225-8329 ๔ 2021 HRMARS

development. In order to survive in a highly competitive business environment, every company should operate under conditions of good performance. Therefore, evaluating the performance of an organization has always been one of the concerns of the management team of organizations and researchers. Researchers have made greater efforts to determine the metrics for the performance concept.

In the era of knowledge economy, sources of economic value and wealth comprises not only from the goods manufactured by enterprises but also their intangible assets, such as intellectual capital. Therefore, intellectual capital will attribute to further role in creating value. In the knowledge based socio-economic period where intellectual capital has become one of the production factors, performance measurements for firm may not be possible with traditional accounting practices anymore (Nuryaman, 2015). Therefore, there is a growing need to develop new methods taking account of the intellectual capital, as it often portrayed as a roof of the organization's performance achievement (Asongu \& Andres, 2019)

According to resource-based theory, the resources existing in an enterprise can be divided into tangible resources and intangible resources. Intellectual capital is an intangible resource, and these resources that meet the criteria of valuable, rare, inimitable, and non-substitutable can provide additional advantages for companies to gain further advantages (Barney, 1991).Intangible resources are one of the key sources of a company's competitive advantage and wealth creation (Adnan, Abdulhamid, \& Sohail, 2018; Jancenelle, 2015; Saddam, 2020; Sumedrea, 2013).

Intellectual capital can be described as a combination of corporate resources that helps in enhancing its sustainable value ( $\mathrm{Xu} \&$ Wang, 2018). To add, this investment portfolio usually composed of human capital, structural capital, and relationship capital is actually a factor that drives firm's performance (Sulanjaku, 2014). Human capital can be associated with the processes involved in coaching, education, and other skill programs to enhance or increase skills, abilities, value, and social assets. Structural capital revolves around the intellectual property rights of a company that is largely independent of employees, such as databases, organizational charts, software, processes, and hardware. Relational capital is the third main component of intellectual capital, which can be defined as valuable assets in the relationship between the company and its stakeholders.

Moreover, according to the research of Ozkan, Cakan, and Kayacan (2017), intellectual capital can be defined as intangible assets, however, these assets are not clearly stated on the company's balance sheet, but completely affect its performance. Since the purpose of the balance sheet is to prepare for reporting purposes, it does not provide data or value based on the actual interests of the company. In addition, the relationship between data obtained from financial reports (generated according to traditional accounting systems) and corporate value has weakened (Kamasak, 2017).In addition, traditional accounting systems cannot reveal the value created by intangible assets in the enterprise (Abiodun, 2014). Therefore, the usefulness of accounting data obtained from financial reports has been declining. Hence, practicality of the accounting data obtained from financial reports has been diminishing. This is further supported by Edvinsson and Malone (1997), the financial statements derived from actual accounting standards does not deliver to the managers the necessary information. Thus, it is difficult to predict or evaluate the company's future financial performance, and its value creating factors. Consequently, the usage of financial statements which "hide" the intangibles can result to wrong decision making. 
INTERNATIONAL JOURNAL OF ACADEMIC RESEARCH IN ACCOUNTING, FINANCE AND

MANAGEMENT SCIENCES

Vol. 11, No. 1, 2021, E-ISSN: 2225-8329 @ 2021 HRMARS

\section{Objective of the Study}

The importance of intellectual capital is undisputable in the current economy; however, the dynamic nature of intellectual capital and firm performance has been disregarded in the past literature. Thus, the objective of this study is to:

- To explain the importance of intellectual capital in knowledge-based economy and in fostering firm's performance.

- To clarify the dynamic relationship (endogeneity) between intellectual capital and firm's performance.

- To enlighten the issues arises in the previous literature by using static model of estimation in studying the relationship between intellectual capital and firm performance.

\section{Literature Review}

\section{Issues on Past Researches on the Relationship between Intellectual Capital and Firm's Performance.}

Studies on intellectual capital and firm performance has been thoroughly studied using static models (Domenico Celenza \& Fabrizio Rossi, 2014; Chen, Cheng, \& Hwang, 2005; Chizari, Mehrjardi, Sadrabadi, \& Mehrjardi, 2016; Chu, Chan, \& Wu, 2011; M Clarke, Seng, \& Whiting, 2011; Dzenopoljac, Janosevic, \& Bontis, 2016; Firer \& Williams, 2003; Gan \& Saleh, 2008; Ghosh \& Mondal, 2009; Kamath, 2007; Kweh, Ting, Le, \& Zhang, 2019; Maditinos, Chatzoudes, Tsairidis, \& Theriou, 2011; Rahman, 2012; Tan, Plowman, \& Hancock, 2008; Vishnu \& Gupta, 2014; Zeghal \& Maaloul, 2010) . But, the static model always unobserved individual-specific, time-invariant effects, and the residual disturbance term has zero mean, constant variance, and is uncorrelated across time and individuals (Brañas-Garza, Bucheli, \& Muñoz, 2011).Moreover, the relationship between intellectual capital and firm performance is bidirectional and hence, dynamic model should be appropriate rather than static (Baltagi, 2001).

Bidirectional relationship occurs when the current value of the independent variable under study is affected by the past value of the dependent variable, thus, dynamic endogeneity occurs, which may lead to estimation bias. Therefore, violation of the strict exogenous assumption in the fixed effect estimator (Arellano \& Bond, 1991). Hence, in this condition, dynamic model is appropriate as existence of endogeneity problems between dependent and independent variables and these regressors may be also correlated with the error term. As such, the regression is unable to control dynamic panel bias. Also, the presence of fixed individual effects so it removes unobserved firms' specific effects. Lastly, dynamic panels also deal with the existence of heteroskedastic and autocorrelation within individuals but not across the entire model. Unfortunately, only few studies cater the endogeneity problems between intellectual capital and firm performance, for example studies by (Al-Hamadanya, Rasheeb, \& Mohammedc, 2020; Nadeem, 2016, 2017; Soetanto \& Liem Pei, 2019; Tran Ngoc, Van Loan, \& Vo Duc, 2020; Wintoki, Linck, \& Netter, 2012; Zhang, 2021). Likewise, research shows that about $90 \%$ of papers published in major journals fail to adequately address endogenous bias (Zhang, 2021). 
INTERNATIONAL JOURNAL OF ACADEMIC RESEARCH IN ACCOUNTING, FINANCE AND MANAGEMENT SCIENCES

Vol. 11, No. 1, 2021, E-ISSN: 2225-8329 @ 2021 HRMARS

The dynamic nature between intellectual capital and firm performance arises as each components of intellectual capital (human capital, structural capital, relational capital and capital employed) requires appropriate investments to accumulate resources. Moreover, the firm's investment in these resources are made to achieve certain goals. For example, a company invests in human capital to increase employee motivation and to generate new ideas. Thus, investment in integrated circuit resources is goal-driven; therefore, the source of these investments is also important for review (Nadeem, 2016).So, the explanation hypothesize that firm's investments are dependent on its past profit. Moreover, companies with poor performance may affect the possibility of their investment in intellectual capital resources. In other words, the current or future years of intellectual capital efficiency will depends on the company's past performance (Nadeem, 2017).

Additionally, companies with high market valuations may choose to invest more in intellectual capital resources in the future (Gupta, Banerjee, \& Onur, 2017).Therefore, the relationship between intellectual capital and firm performance is dynamic instead static as the relationship is two way and the endogeneity problem in intellectual capital (independent variable). In brief, the relationship between the current year independent variable and the lagged year dependent variable will lead to unfair result if static model for example POLS, Fixed effect (FE) or Random effect (RE) are used (AlHamadanya et al., 2020; Nadeem, 2016, 2017; Soetanto \& Liem Pei, 2019; Tran Ngoc et al., 2020; Wintoki et al., 2012; Zhang, 2021). As, static panels is only consistent when all the explanatory variables are exogenous and do not correlate with the individual specific effects. However, since the POLS estimator does not consider the model error structure, the estimator is ineffective for this study. Moreover, endogenous bias may lead to inconsistent estimates and wrong inferences, which may provide misleading conclusions and inappropriate theoretical explanations (Zhang, 2021). Sometimes this deviation may even lead to the wrong sign of the coefficient (Ullah, Akhtar, \& Zaefarian, 2018).Furthermore, when the lagged-dependent variables are included in the model, the POLS estimator becomes biased due to the correlation between the dependent variables and the individual-specific effects of either permanent or random effects. Therefore, in this situation it is concluded that intellectual capital is endogenous and will only provide robust result with Generalized Method of Moment (GMM).

Accordingly, Soetanto and Liem Pei (2019) proposed to use dynamic panel data regression by Blundell and Bond (1998) system generalized method of moment (GMM) estimator to produce reliable results. In order to obtain vigorous estimates, a Generalized Method of Moment (GMM) panel estimator is suggested. GMM proposed by Arellano and Bond (1991) is due to the potential endogeneity of independent variables, inclusion of the lagged dependent variable and the presence of the firm-specific effects.

Consequently, in this study to capture the dynamic relationship between intellectual capital and firm performance, dynamic panel regression is suggested. Therefore, it may be attributing to both relationship between independent and dependent variable and these regressors may be also correlated with the error term. As such, the regression is unable to control dynamic panel bias. Next, the time invariant characteristic i.e. fixed effects namely demographics and geography may be correlated with the explanatory variables. The error terms in the regression which are consist of 
INTERNATIONAL JOURNAL OF ACADEMIC RESEARCH IN ACCOUNTING, FINANCE AND MANAGEMENT SCIENCES

Vol. 11, No. 1, 2021, E-ISSN: 2225-8329 ๑ 2021 HRMARS

unobserved specific effect and the observation specific effect respectively are founded in the fixed effects. Hence, dynamic model could help in solving endogeneity problem for this study in the independent variable of intellectual capital(intellectual capital including human capital. Structural capital, relational capital and capital employed). Unfortunately, previous researches using static estimators such as POLS and FE or RE cannot accommodate endogenous relationship. Endogeneity is a common problem in statistics, econometrics, sociology, biology, and other related sciences (Zhang, 2021). When discussing regression models, endogeneity means that some related regression variables are related to error terms, which leads to regression functions that deviate from the true conditional mean function. If the potential endogeneity is ignored, estimates based on conventional techniques will always be biased and inconsistent (Al-Hamadanya et al., 2020).

Intellectual capital and firm performance are mean to be endogenous because current performance can be influenced by prior performance. It also accounts for a reverse causality from performance to intellectual capital (Al-Hamadanya et al., 2020). According to Babajee, Seetanah, and Nunkoo (2020) this endogenous relationship can be described when a high ROA may have a motivating effect on managers, and managers may encourage their employees to perform better. Consequently, the higher the ROA, the stronger the company's ability to use for training and research and development activities, which can add value to the company. These evidences show that the relationship between intellectual capital components and company performance is not only one-way, but also two-way, which means that lagged company performance will affect intellectual capital efficiency in the current year or the next year. Hence, GMM estimator is suggested to control the endogeneity. An effective way to solve endogeneity is to use instrumental variables to replace the endogenous variable, these variables are closely related to the endogenous regression variables, but have nothing to do with the error term (Zhang, 2021). Secondly, it can be catered by adding lags to the endogenous variable. Facts have proved that the Generalized Method of Moments (GMM) is an effective method to solve the endogeneity problem in the classic linear regression model (Hansen, 1982).

Recently, a study by Al-Hamadanya et al. (2020) specified that all the research conducted between intellectual capital and firm performance have been based on static model and fails to cater reverse causality and endogeneity. Thus, the study suggested for a more sophisticated methodological approach using dynamic model. Therefore, the dynamic model would allow future studies to examine the direct, indirect, and endogenous effects.

Considering the endogeneity problem between intellectual capital and firm performance that has been disregarded in the majority of the past researches, hence, this study aims to take into the consideration on the dynamic nature between intellectual capital and firm performance. Previously, (D Celenza \& F Rossi, 2014; Domenico Celenza \& Fabrizio Rossi, 2014; Chen et al., 2005; Chizari et al., 2016; Chu et al., 2011; Martin Clarke, Seng, \& Whiting Rosalind, 2011; Dzenopoljac et al., 2016; Firer \& Williams, 2003; Gan \& Saleh, 2008; Ghosh \& Mondal, 2009; Kamath, 2007; Kweh et al., 2019; Maditinos et al., 2011; Rahman, 2012; Tan et al., 2008; Vishnu \& Gupta, 2014; Zeghal \& Maaloul, 2010) research on intellectual capital and firm's financial performance has been using static model 
INTERNATIONAL JOURNAL OF ACADEMIC RESEARCH IN ACCOUNTING, FINANCE AND MANAGEMENT SCIENCES

Vol. 11, No. 1, 2021, E-ISSN: 2225-8329 @ 2021 HRMARS

for the methodology. However, using static model such as pooled ordinary lest squares method failed to obtain the correlation between the company's variables over the years (Maji \& Goswani, 2017).

Endogeneity may be caused by the omission of explanatory variables in the regression, which will cause the error term to be associated with the explanatory variables, thus violating the basic assumptions behind ordinary least squares (POLS) regression analysis. Secondly, this may also because the dependent variable is affected by one or more explanatory variables, and these explanatory variables are in turn affected by the dependent variable. This endogeneity can happen at the same time. Therefore, the simultaneous realization of related variables and explanatory variables will affect each other. Thirdly, it can be a dynamic type, the past realization of the dependent variable will affect the current realization of one or more explanatory variables.

As mentioned above, there are very limited studies to cater endogeneity issues in current research area. The first study to test on dynamic nature between intellectual capital and firm performance has been done by Nadeem (2017). The study was conducted in BRICS economies by applying the Arellano-Bond two-step system GMM estimator to measure the dynamic relationship. The main aim of this study is to address the important of econometric problems such as endogeneity which past studies overlooked. Additionally, a study by Tran and Vo (2018) also the first to employ GMM method in the banking context to solve endogeneity problem. This study was conducted in Thai banking industry using lagged dependent variable as an instrumental variable.

Recently, in the literature, the dynamic aspects of intellectual capital have been considered, because researchers suspect that the influence of intellectual capital on financial performance not only exists in the current period, but also in the future (Al-Hamadanya et al., 2020; Nadeem, 2017; Sardo \& Serrasqueiro, 2018; Soetanto \& Liem Pei, 2019; Tran Dai \& Vo Duc, 2018) .Then, the lagging value of intellectual capital is confirmed to be beneficial to current profitability (ROA and ROE) (Meles, Porzio, Sampagnaro, \& Verdoliva, 2016; Sardo \& Serrasqueiro, 2018).

\section{Issues in Estimating Static Panel Models}

The Pooled Ordinary Least Squares (POLS) method is commonly used to estimate the parameters of linear regression models. The POLS estimator minimizes the sum of squared errors (the difference between the observed value and the predicted value). Although POLS is computationally practicable and can be easily used in any econometric test, it is important to understand the basic assumptions of POLS regression. Unfortunately, OLS method is only consistent when all the explanatory variables are exogenous and does not correlate with individual specific effects. Since the POLS estimator does not consider the model error structure, the estimator is inefficient.

In addition, when the lagged dependent variable is included in the model, the POLS estimator will become biased due to the correlation between the dependent variable and the individual-specific effects of permanent or random effects. When the dependent variable is functionally specific to the effect of Fixed effect or Random effect (FE or RE), then the lagged dependent variable will also contribute to the specific effect. Therefore, the lagging dependent variable is related to the error 
INTERNATIONAL JOURNAL OF ACADEMIC RESEARCH IN ACCOUNTING, FINANCE AND MANAGEMENT SCIENCES

Vol. 11, No. 1, 2021, E-ISSN: 2225-8329 @ 2021 HRMARS

term. Even if the error term has no serial correlation, this will cause the POLS estimator to be biased and inconsistent.

The biased and inconsistency of the POLS estimator is due to the correlation between the lagged dependent variable and the individual-specific effect. So, by transforming the FE model, specific effects can be removed or dealt with. Then derived the new error clause. FE model are designed to study the courses, explore the relationship between predictor and outcome variables within an entity, and it is easy to estimate and concerned the individual characteristics of each firms in the sample. As FE allows for correlation between the effect and the covariates. However, the estimator will still bias, as the $T$ is with a lower data frequency. Also, FE models cannot estimate about the relationships with independent variables that do not change over time, only for deviations from the mean over time. FE models therefore "throw away important and useful information about the relation between the explanatory and the explained variables in a panel" (Nerlove, 2005). Therefore, FE model is not appropriate to be use in this study.

Estimation using the Generalized least squares regression (GLS) method to estimate panel data for the estimated RE model encounters the same problems as the estimated in the FE model. This is because in order to use the GLS method, quasi-demographic data must be performed, which causes the variables to be correlated with the variance. The random effects model (RE) cannot control endogenous and unobservable things, and requires strict erogeneity, so it is orthogonal to the covariates. The basic principle of using RE is that the purpose of this research is to understand the differences between the hypotheses and the predictors or independent variables included in the model. This allows time-invariant variables to act as explanatory variables. In RE, we need to specify those individual characteristics that may not affect the predictor variables. The problem with $R E$ is that some variables may not be available, which leads to the omission of variable bias in the model. Thus, the GLS estimator is also biased and inconsistent.

From the discussion above, the problem of endogenous biases appear in explanatory variables, the dynamic effects of lagged variable and the existence of firm-specific effects or so-called (Nickell, 1981) biases is impossible to solve using static panel estimation (Al-Hamadanya et al., 2020; Nadeem, 2017; Soetanto \& Liem Pei, 2019). Therefore, dynamic model is required to cater endogeneity problem by adding lagged to the endogenous variable or by replacing the endogenous variable by using new variable called instrumental variable. Additionally, previous studies also consider the endogeneity in the research of intellectual capital and firm performance (Al-Hamadanya et al., 2020; Nadeem, 2016, 2017; Soetanto \& Liem Pei, 2019; Tran Ngoc et al., 2020; Wintoki et al., 2012; Zhang, 2021). Thus, the Generalized Method of Moment (GMM) introduced by (Arellano \& Bond, 1991) solves this problem.

\section{Conclusion}

In the present knowledge-based economy era, intellectual capital literatures have revealed the importance of intangible assets to corporate finance and market performance. Also, scholars and practitioners are paying more and more attention to it. Intellectual capital has always been considered as a key value driver for companies doing business in fostering the firm performance. Yet, most of the studies in the past connecting intellectual capital and firm performance applied a static model of estimation. Though, the static model may not be able to resolve the reverse causality and endogeneity related to the relationship. Because, dynamic effects of lagged variable and the 
INTERNATIONAL JOURNAL OF ACADEMIC RESEARCH IN ACCOUNTING, FINANCE AND MANAGEMENT SCIENCES

Vol. 11, No. 1, 2021, E-ISSN: 2225-8329 @ 2021 HRMARS

existence of firm-specific effects (Nickell, 1981) biases is impossible to solve using static panel estimation. Endogeneity in the regression model refers to an explanatory variable (endogenous, such as human capital, structural capital, relational capital and capital employed in this study) is related to the error term. Therefore, endogenous bias may lead to inconsistent estimation results (it often becomes the true value as the number of samples increases), which may lead to wrong inferences, misleading conclusions and wrong theoretical explanations (Zhang, 2021).Therefore, this study suggesting future research to take into consideration on the reverse-causality relationship between firm performance and intellectual capital by applying dynamic panel data estimation in the future. Furthermore, this study provides methodological gap by applying dynamic panel model estimation between intellectual capital and firm performance. Consequently, using the dynamic model, it helps in shifting from the prior methodological approaches which provides biased results to a more sophisticated approach.

\section{References}

Adnan, M., Abdulhamid, T., \& Sohail, B. (2018). Predicting Firm Performance through Resource Based Framework. European Journal of Business and Management, 10(1).

Al-Hamadanya, R. I., Rasheeb, I. M., \& Mohammedc, M. D. (2020). A Systematic Review of Literature on Intellectual Capital in the Gulf Cooperation Countries. International Journal of Innovation, Creativity and Change., 1(10).

Arellano, M., \& Bond, S. (1991). Some Tests of Specification for Panel Data: Monte Carlo Evidence and an Application to Employment Equations. The Review of Economic Studies, 58(2), $277-$ 297.

Asongu, S. A., \& Andres, A. R. (2019). Trajectories of knowledge economy in SSA and MENA countries. Technology in Society.

Babajee, R. B., Seetanah, B., \& Nunkoo, R. (2020). The determinants of hotel financial performance: an intellectual capital perspective. Journal of Hospitality Marketing \& Management, 29(8), 1008-1026.

Baltagi, B. H. (2001). Econometric Analysis of Panel Data (2nd ed.): New York: Wiley.

Barney, J. (1991). Firm Resources and Sustained Competitive Advantage. Journal of Management, 17(1), 99-120.

Blundell, R., \& Bond, S. (1998). Initial conditions and moment restrictions in dynamic panel data models. Journal of Econometrics, 87(1), 115-143.

Brañas-Garza, P., Bucheli, M., \& Muñoz, T. (2011). Dynamic panel data: A useful technique in experiments.

Celenza, D., \& Rossi, F. (2014). Intellectual capital and performance of listed companies: empirical evidence from Italy. Measuring Business Excellent, 18(1), 23.

Celenza, D., \& Rossi, F. (2014). Intellectual capital and performance of listed companies: Empirical evidence from Italy. Measuring Business Excellence, 18.

Chen, M. C., Cheng, S. J., \& Hwang, Y. (2005). An empirical investigation of the relationship between intellectual capital and firms' market value and financial performance. Journal of Intellectual Capital, 6(2), 159-176. 
INTERNATIONAL JOURNAL OF ACADEMIC RESEARCH IN ACCOUNTING, FINANCE AND

MANAGEMENT SCIENCES

Vol. 11, No. 1, 2021, E-ISSN: 2225-8329 ๔ 2021 HRMARS

Chizari, M. h., Mehrjardi, R. Z., Sadrabadi, M. M., \& Mehrjardi, F. K. (2016). The impact of Intellectual Capitals of Pharmaceutical Companies Listed in Tehran Stock Exchange on their Market Performance. Procedia Economics and Finance, 36, 291-300.

Chu, S. K. W., Chan, K. H., \& Wu, W. Y. (2011). Charting intellectual capital performance of the gateway to China. Journal of Intellectual Capital, 12(2), 249-276.

Clarke, M., Seng, D., \& Whiting, R. H. (2011). Intellectual capital and firm performance in Australia. Journal of Intellectual Capital, 12(4), 505-530.

Clarke, M., Seng, D., \& Whiting Rosalind, H. (2011). Intellectual capital and firm performance in Australia. Journal of Intellectual Capital, 12(4), 505-530.

Dzenopoljac, V., Janosevic, S., \& Bontis, N. (2016). Intellectual capital and financial performance in the Serbian ICT industry. Journal of Intellectual Capital, 17(2), 373-396.

Edvinsson, L., \& Malone, M. (1997). Intellectual Capital: Realizing Your Company's True Value by Finding Its Hidden Brainpower: HarperCollins.

Firer, S., \& Williams, M. (2003). Intellectual Capital and Traditional Measures of Corporate Performance. Journal of Intellectual Capital, 4, 348-360.

Gan, K., \& Saleh, Z. (2008). Intellectual capital and corporate performance of technology-intensive companies: Malaysia evidence. Asian Journal of Business and Accounting, 1.

Ghosh, S., \& Mondal, A. (2009). Indian software and pharmaceutical sector IC and financial performance. Journal of Intellectual Capital, 10, 369-388.

Gupta, K., Banerjee, R., \& Onur, I. (2017). The effects of R\&D and competition on firm value: international evidence. international", Review of Economics and Finance, 51, 391-404.

Hansen, L. P. (1982). Large sample properties of generalized method of moments estimators. Econometrica: Journal of the Econometric Society, 1029-1054.

Jancenelle, V. E. (2015). The relationship between firm resources and joint ventures: revisited. American Journal of Business, 30(1), 8-21.

Kamasak, R. (2017). The contribution of tangible and intangible resources, and capabilities to a firm's profitability and market performance. European Journal of Management and Business Economics, 26(2), 252-275.

Kamath, G. B. (2007). The intellectual capital performance of Indian banking sector. Journal of Intellectual Capital, 8(1), 96-123.

Kweh, Q. L., Ting, I., Le, H., \& Zhang, C. (2019). Intellectual capital, governmental presence, and firm performance of publicly listed companies in Malaysia. International Journal of Learning and Intellectual Capital, 16, 193.

Maditinos, D., Chatzoudes, D., Tsairidis, C., \& Theriou, G. (2011). The impact of intellectual capital on firms' market value and financial performance. Journal of Intellectual Capital, 12(1), 132-151.

Maji, S. G., \& Goswani, M. (2017). Intellectual capital and firm performance in India: a comparative study between original and modified value added intellectual coefficient model. International Journal of Learning and Intellectual Capital, 14(1).

Meles, A., Porzio, C., Sampagnaro, G., \& Verdoliva, V. (2016). The impact of the intellectual capital efficiency on commercial banks performance: Evidence from the US. Journal of Multinational Financial Management, 36, 64-74.

Nadeem, M. (2016). Intellectual Capital and Firm Performance: Static or Dynamic Estimation: Evidence From the UK. 
INTERNATIONAL JOURNAL OF ACADEMIC RESEARCH IN ACCOUNTING, FINANCE AND

MANAGEMENT SCIENCES

Vol. 11, No. 1, 2021, E-ISSN: 2225-8329 @ 2021 HRMARS

Nadeem, M. (2017). Does intellectual capital efficiency improve firm performance in BRICS economies? A dynamic panel estimation. Measuring Business Excellence, 21.

Naz, F., \& ljaz, F. (2016). Financial Performance of Firms: Evidence from Pakistan Cement Industry. Journal of Teaching and Education.

Nerlove, M. (2005). Essays in panel data econometrics: Cambridge University Press.

Nickell, S. (1981). Biases in Dynamic Models with Fixed Effects. Econometrica, 49(6), 1417-1426.

Nuryaman, N. (2015). The Influence of Intellectual Capital on The Firm's Value with The Financial Performance as Intervening Variable. Procedia - Social and Behavioral Sciences, 211, 292-298.

Ozkan, N., Cakan, S., \& Kayacan, M. (2017). Intellectual capital and financial performance: A study of the Turkish Banking Sector. Borsa Istanbul Review, 17(3), 190-198.

Rahman, S. (2012). The role of intellectual capital in determining differences between stock market and financial performance. International Research Journal of Finance and Economics, 89, 4677.

Saddam, S. Z. (2020). The Motivation of Intellectual Capital on Fir? s Financial Performance: Analysis on Financial Sector in Malaysia. International Journal of Academic Research in Accounting, Finance and Management Sciences, 10.

Sardo, F., \& Serrasqueiro, Z. (2018). Intellectual capital, growth opportunities, and financial performance in European firms: Dynamic panel data analysis. Journal of Intellectual Capital, 19(4), 747-767.

Soetanto, T., \& Liem Pei, F. (2019). Intellectual capital in Indonesia: dynamic panel approach. Journal of Asia Business Studies, 13(2), 240-262. doi:10.1108/JABS-02-2018-0059

Sulanjaku, M. (2014). The Contribution of Skandia Navigator in Intangibles Measurements. SSRN Electronic Journal.

Sumedrea, S. (2013). Intellectual Capital and Firm Performance: A Dynamic Relationship in Crisis Time. Procedia Economics and Finance, 6, 137-144. doi:10.1016/s2212-5671(13)00125-1

Tan, H., Plowman, D., \& Hancock, P. (2008). The evolving research on intellectual capital. Journal of Intellectual Capital, 9, 585-608.

Tran Dai, B., \& Vo Duc, H. (2018). Should bankers be concerned with Intellectual capital? A study of the Thai banking sector. Journal of Intellectual Capital, 19(5), 897-914.

Tran, D. B., \& Vo, D. H. (2018). Should bankers be concerned with Intellectual capital? A study of the Thai banking sector. Journal of Intellectual Capital, 19(5), 897-914.

Tran Ngoc, P., Van Loan, T.-H., \& Vo Duc, H. (2020). The nexus between corporate governance and intellectual capital in Vietnam. Jorunal of Asia Business Studies.

Ullah, S., Akhtar, P., \& Zaefarian, G. (2018). Dealing with endogeneity bias: The generalized method of moments (GMM) for panel data. Industrial Marketing Management, 71, 69-78.

Vishnu, S., \& Gupta, V. (2014). Intellectual capital and performance of pharmaceutical firms in India. Journal of Intellectual Capital, 15.

Wintoki, M. B., Linck, J. S., \& Netter, J. M. (2012). Endogeneity and the dynamics of internal corporate governance. Journal of Financial Economics, 105(3), 581-606. Retrieved from https://EconPapers.repec.org/RePEc:eee:jfinec:v:105:y:2012:i:3:p:581-606

Xu, J., \& Wang, B. (2018). Intellectual Capital, Financial Performance and Companies' Sustainable Growth: Evidence from the Korean Manufacturing Industry. Sustainability, 10(12), 4651. 
INTERNATIONAL JOURNAL OF ACADEMIC RESEARCH IN ACCOUNTING, FINANCE AND MANAGEMENT SCIENCES

Vol. 11, No. 1, 2021, E-ISSN: 2225-8329 @ 2021 HRMARS

Zeghal, D., \& Maaloul, A. (2010). Analysing value added as an indicator of intellectual capital and its consequences on company performance. Journal of Intellectual Capital, 11(1), 39-60.

Zhang, H.-F. (2021). Iterative GMM for partially linear single-index models with partly endogenous regressors. Computational Statistics \& Data Analysis, 156, 107145. 